\title{
Comparison of several EPA-recommended US and German well-head protection area delineation methods in agricultural settings
}

\author{
RO Strobl ${ }^{1 *}$ and PD Robillard ${ }^{2}$ \\ ${ }^{1}$ Water Resources Department, International Institute for Geo-Information Science and Earth Observation, Hengelosestraat 99,7514 \\ AE Enschede, The Netherlands \\ 2 World Water Watch, 955 Massachusetts Avenue, \#263, Cambridge, MA 02139, USA
}

\begin{abstract}
Preventive measures for protecting water supplies from contamination necessitates the delineation of well-head protection areas (WHPAs), in which potentially groundwater-endangering activities are strictly regulated and monitored. In the case of private well operators in agricultural settings, there generally exists greater control of restricting and regulating particular land uses in the proximity of a well-head, than in municipal settings. However, due to typically limited and strained financial resources of farm operators, alternative and affordable WHPA delineation methods would be of great advantage. Consequently, relatively simple and inexpensive well-established German WHPA delineation models were evaluated to several typically more cost-intensive United States Environmental Protection Agency (EPA)-recommended WHPA delimitation methods in three agricultural settings, located in south-eastern Pennsylvania. The delineation results revealed that several of the German approaches compared fairly well with the more advanced numerical module, which is recommended by the EPA. Hence, German WHPA delineation methods may provide a viable alternative for WHPA delineation in agricultural settings.
\end{abstract}

Keywords: well-head protection area, private water supply, delineation method

\section{Introduction}

The contamination of groundwater by harmful substances has many natural and anthropogenic causes. A significant portion of groundwater contamination is associated with agricultural land uses. In fact, the contamination of groundwater in agricultural settings has increased with the intensification, specialisation, and mechanisation of agricultural production. Intensive agricultural and horticultural land utilisation calls for the optimal combination of inputs to achieve high yields and, therefore, maximise profits. In regions with intensive livestock farming, manure has become a troublesome waste product and can directly impact surface and groundwater quality. The impact on drinking water supplies from agricultural operations is of particular concern in intensive processing regions and where high value specialty crops are grown. Because the quantity and quality of drinking water demands are increasing, there is greater demand for groundwater protection.

Well-head protection ultimately decreases the risk of water supply contamination. In the long run, well-head protection is designed to prevent expensive groundwater clean-up operations or well-field relocation. The main feature in well-head protection is the delineation of the well-head protection area (WHPA), which is the mapping of the area under the WHPA. This area typically can range from less than a hundred metres to several kilometres from a well (Lennox, 1993). Moreover, the delineation of a WHPA involves investigating the water-bearing zone

\footnotetext{
* To whom all correspondence should be addressed.

용 +31 (0)53 4874-282; fax: +31 (0)53 4874-336;

e-mail: strobl@itc.n1 or rostrobl@yahoo.com

Received 15 July 2005; accepted in revised form 22 June 2006.
}

for its soil cover type, thickness, quality, productivity, depth to groundwater, present land uses, as well as potential threats originating from the surface above the water-bearing zone. Generally speaking, it is the land surface surrounding a well, well-field, or spring into which contaminants are likely to enter (Cleary and Cleary, 1991; EPA, 1987). Therefore, outlining a protection area around wells and springs is the basis for developing a contamination control system. Within this protection area, activities are managed to prevent further sources of contamination. It is important to define a sufficient protection area so that contaminants from beyond the boundary can be treated or diverted before reaching the water supply.

Due to the higher threat of contamination of non-public wells in agricultural settings, cost-effective, but reliable, delineation methods are urgently needed. As noted by Doscher (1992), particularly private well operators in agricultural regions are often financially constrained, however; normally have greater control in regulating and restricting land uses in the recharge areas of their water supply. Strobl and Robillard (2005) provided a brief overview of EPA (1987)-recommended WHPA delineation methods (Blandford and Huyakorn, 1991; 1993) as well as indepth examinations of some well-established German WHPA delineation approaches. It should be noted that these delineation methods were derived exclusively for porous aquifers and are not suitable for use in fractured rock environments. Strobl and Robillard (2005) concluded that in order to evaluate the applicability and validity between the methods when employed in private water supplies in agricultural settings, specific case studies need to be performed. In this paper, WHPA delineation case studies will be used to compare different delineation methods. A comparison of the outer boundaries of the respective WHPAs is made and the probable amount of under-protection or overprotection estimated. Furthermore, the effects of 
neglecting or considering the regeneration parameter of aquifers will be evaluated.

\section{Evaluation and analysis of case studies}

In Doscher's (1992) study of four farmsteads in Lancaster County, Pennsylvania, field surveys of each site were conducted in order to apply EPA-recommended WHPA delineation methods which could be used with the secondary data available. The delineations simulated drought conditions where no recharge had occurred over a 180d period. In addition, a broad range of hydraulic conductivity values for the type of rock formation found at each site were selected due to the spatial variability of the hydraulic conductivity (Doscher, 1992). The interval of the well open to the aquifer was assumed to be representative of the aquifer thickness, while the field survey helped to determine the well discharge. Doscher (1992) also assumed that the surface topography was reflective of the water table elevations. This assumption made it possible to obtain the hydraulic gradient as well as the directions of groundwater flow from the surface topography. In addition, two-dimensional horizontal flow occurring only in saturated bedrock was assumed in order to simulate the case studies.

While the EPA-recommended arbitrary fixed radius method, calculated fixed radius method, various analytical methods, and a numerical method were applied by Doscher (1992), the simple variable shapes and hydrogeological mapping methods could not be executed for the case studies due to insufficient data. For the numerical and analytical methods, the WHPA computer model, developed by the EPA specifically for the delineation of WHPAs, was used. Three computationally independent modules, namely MWCAP (multiple well-capture zone), RESSQC (regional sources and sinks flow in the capture zone), and GPTRAC (general particle tracking), constitute the WHPA model. The MWCAP and RESSQC modules are purely analytical, while the GPTRAC module consists of a semi-analytical and numerical option. With the MWCAP module, it is possible to delineate capture zones for steady-state, transit, or hybrid conditions for single or multiple wells. Whereas MWCAP has the ability to include stream or boundary barriers, RESSQC cannot handle such conditions. The semi-analytical option of the GPTRAC module, on the other hand, can compute flow-paths and timerelated capture zones by similar techniques used in the MWCAP and RESSQC modules. Furthermore, the numerical option of the GPTRAC module computes flow-paths and capture zones by using hydraulic heads as input to a finite difference mesh. In addition, a Monte Carlo computational technique that accounts for random effects and uncertainties due to heterogeneities or hydrologic variations can be employed in the WHPA computer model.

For consistent reference, the sequence of the sites used in Doscher's (1992) study is utilised and the results from Doscher's (1992) study are presented in selected figures together with the German WHPA delineation models' results. However, only Sites 2 to 4 of Doscher's (1992) study could be evaluated. Site 1 of Doscher's (1992) study exhibited a 'curved' groundwater flow direction, and therefore violated the assumption of an essentially straight principal flow axis, inherent in all of the examined German WHPA delineation models.

Furthermore, several of the German WHPA delineation methods discussed in a previous paper could not be applied to the case studies by Doscher, 1992). The approach by Hofmann and Lillich (1973), for example, could not be evaluated since the horizontal distance from the centre of the pumping

\begin{tabular}{|l|l|l|}
\hline \multicolumn{3}{|c|}{$\begin{array}{c}\text { TABLE 1 } \\
\text { Minimum and maximum transmissivity } \\
\text { values used by Doscher (1992) }\end{array}$} \\
\hline Site & $\mathrm{T}_{\min }$ (m $\mathbf{m}^{2} /$ day) & $\mathrm{T}_{\max }$ ( $^{2} /$ day) \\
\hline 1 & 0.068 & 6828 \\
\hline 2 & 0.004 & 3726 \\
\hline 3 & 0.006 & 6210 \\
\hline 4 & 0.007 & 6828 \\
\hline
\end{tabular}

well to the onset of the drawdown was not known for any of the sites. Nahrgang's (1965) method, on the other hand, could not be applied since a detailed flow map was not available. Two of the German aquifer regeneration accounting methods, namely the approaches by Bolsenkötter et al. (1984) and Renner (1972), were also not applicable. While fractured covering layers were not known to exist in the unsaturated zone for Bolsenkötter et al.'s (1984) method to be valid, Renner's (1972) technique was not applicable because the maximum apparent groundwater flow velocity was unknown at all of the sites.

Estimated minimum and maximum transmissivity values $\left(\mathrm{T}_{\min }\right.$ and $\left.\mathrm{T}_{\max }\right)$ were applied in all case studies to investigate the extremes of delineated WHPA shapes obtained under different hydrogeological assumptions. The $\mathrm{T}_{\min }$ and $\mathrm{T}_{\max }$ for all studied sites were estimated by Doscher (1992) from published values of hydraulic conductivity and geological site data, and are listed in Table 1.

\section{Case studies}

\section{Site 2}

Site 2 in Doscher's (1992) study is a dairy farm located at approximately $39^{\circ} 47^{\prime}$ north latitude and $76^{\circ} 07^{\prime}$ ' west longitude in southern Lancaster County, Pennsylvania. The farm buildings in question are located on a local topographic high at an approximate elevation of $150 \mathrm{~m}$ above sea level. The well-bore is situated in the centre of the farm buildings and is sealed and protected by a wooden box. In addition, mounded grass surrounds the well-bore. From a USGS geological map it was found that the well is drilled in the Peters Creek schist aquifer. Possible contamination sources are a large barn, located adjacent to the well-head and surrounded on the east and south by an extensive livestock confinement area and turn-out field, a large manure storage pit, situated north of the corn crib and up-gradient from the well-head, a septic tank, located southeast of the house and south of the well-bore, a leach field, situated approximately $3 \mathrm{~m}$ up-gradient from the septic tank, a heifer barn, located up-gradient of the well, and cropland, surrounding the farm to the east and north. The relative location of the buildings and possible contamination sources are depicted in Fig. 1. Furthermore, the angle of ambient groundwater flow was determined to be $231^{\circ}$. Doscher (1992) estimated a daily water use of 12776 l/d.

\section{Delineation results of the EPA-suggested methods for Site 2 (Doscher, 1992)}

\section{Arbitrary fixed radius method}

Doscher (1992) selected arbitrary radii of $15.2 \mathrm{~m}, 30.5 \mathrm{~m}$, and $121.9 \mathrm{~m}$. While the $15.2 \mathrm{~m}$ radius area did not include any major contamination sources, the $30.5 \mathrm{~m}$ radius area contained segments of the heifer containment area, milking barn, house, and equipment barn. The $121.9 \mathrm{~m}$ radius area, on the other hand, 


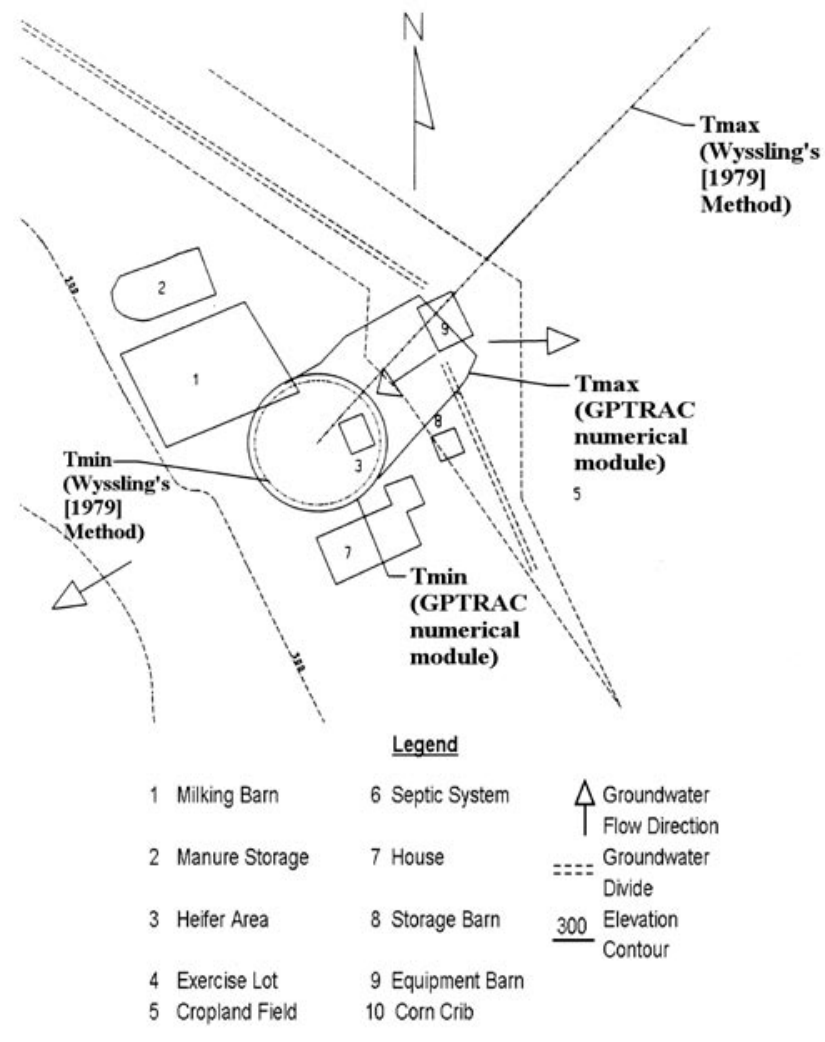

Figure 1

GPTRAC numerical module's (Doscher, 1992) and Wyssling (1979) method's results for Site 2

embraced all farm buildings, exercise lots, the leach field, the septic tank, as well as major portions of cropland.

\section{Calculated fixed radius method}

The calculated fixed radii obtained from the volumetric method for 1-year, 5-year, and 20-year times of travel (TOTs) by Doscher (1992) were computed as $40.2 \mathrm{~m}, 89.9 \mathrm{~m}$, and $179.8 \mathrm{~m}$, respectively. Therefore, the 1-year radius area included slightly more area than the $30.5 \mathrm{~m}$ arbitrary fixed radius area. While the 5 -year radius area embraced all farm buildings, the septic tank, portions of the leach field, turn-out lot, and cultivated field to the north of the heifer barn, as well as the heifer barn and manure storage pit, the 20 -year radius area extended beyond the study area boundaries.

\section{Analytical models}

Applying the given $\mathrm{T}_{\max }$ value to the RESSQC module, the delineation furnished a $30.5 \mathrm{~m}$ wide area oriented along the inferred direction of groundwater flow, while the delineation using the chosen $T_{\min }$ value produced an unidentifiable result. Therefore, Doscher (1992) increased the $T_{\min }$ value to $9.29 \mathrm{~m}^{2} / \mathrm{d}$. This change brought about an area with a $27.13 \mathrm{~m}$ radius that included a minor part of the heifer containment area. Using the chosen $\mathrm{T}_{\max }$ value with the MWCAP module, on the other hand, yielded a straight, narrow line of $47 \mathrm{~m}$ length. Unfortunately, the width of the $\mathrm{T}_{\max }$ area could not be determined with certainty. However, the $\mathrm{T}_{\max }$ area did pass through a portion of the heifer containment area. The delineation using the pre-selected $\mathrm{T}_{\min }$ value, on the other hand, yielded an approximate circle that embraced portions of the heifer containment area and milking barn, as well as the entire house. Nearly identical results were produced by the GPTRAC semi-analytical and MWCAP modules. While the delineation using the chosen $\mathrm{T}_{\text {max }}$ value yielded a straight line of $141.7 \mathrm{~m}$ length, directed along the direction of groundwater flow, the delineation of the given $\mathrm{T}_{\min }$ value produced a circle with a radius of $32 \mathrm{~m}$.

\section{Numerical model}

An irregular tear-drop shape enclosing a circle with an approximate radius of $16.5 \mathrm{~m}$ resulted from the delineation using the selected $\mathrm{T}_{\min }$ value with the GPTRAC module. This area embraced portions of the heifer containment area and milking barn. The delineation using the chosen $\mathrm{T}_{\max }$ value included all delineated area from the $T_{\min }$ value and also additional area in the direction of groundwater flow and beyond the groundwater divide.

\section{Delineation results of the German methods for Site 2}

\section{Wyssling (1979)}

The $\mathrm{T}_{\max }$ delineation resulted in a straight, very narrow line with a length of $3500 \mathrm{~m}$. Obviously, this delineation extends beyond the study boundaries. However, one of the necessary steps after delineating a protection zone is to adjust the delineated area to account for stream boundaries, local groundwater divides, etc., since this model does not incorporate local boundaries. The $\mathrm{T}_{\max }$ area passed through the heifer containment area and is oriented along the inferred direction of groundwater flow. The $\mathrm{T}_{\text {min }}$ delineation, on the other hand, yielded a circle with a radius of $14.9 \mathrm{~m}$ and embraced the heifer containment area as well as an extremely small portion of the milking barn.

The $\mathrm{T}_{\max }$ area delineation result between this method and the RESSQC module did not compare very well. For instance, the $\mathrm{T}_{\max }$ area of the RESSQC module comprised a much wider area, even though it was oriented in the same direction. On the other hand, the $\mathrm{T}_{\max }$ area delineation results were very similar for the Wyssling (1979) method, MWCAP module, and GPTRAC semi-analytical module. The $\mathrm{T}_{\text {min }}$ area from the Wyssling (1979) method included slightly less area than the EPA-suggested analytical methods. Nevertheless, Fig. 1 shows that the $T_{\min }$ area from the GPTRAC numerical module is nearly identical to the results from Wyssling's (1979) method. However, these results could be identical if an additional safety margin, as suggested by Wyssling (1979), is used to buffer the protection area after delineation calculations. The $T_{\max }$ area from the GPTRAC numerical module, on the other hand, was much wider and, hence included more potential contamination sources.

\section{Spitz et al. (1980)}

In order to use Spitz et al.'s (1980) method, the longitudinal dispersivity needs to be estimated. A longitudinal dispersivity value of $0.1 \mathrm{~m}$ was selected for the Peters Creek schist aquifer at Site 2. However, the $\mathrm{T}_{\max }$ delineation using this method could not be performed due to computational difficulties. In contrast, the $\mathrm{T}_{\min }$ computation resulted in a circular shape with an approximate average radius of $18 \mathrm{~m}$ and included a portion of the milking barn. Up-gradient and down-gradient dispersivity factors with a value of 1.0 each were determined and indicate that for the selected $\mathrm{T}_{\min }$ value, there are no observable dispersion effects.

The $\mathrm{T}_{\min }$ areas delineated by the MWCAP and GPTRAC semi-analytical modules were shown to cover more area due to their greater defining radii. In other words, the MWCAP and GPTRAC semi-analytical modules encompassed a greater portion of the barn as well as almost the entire farm house. Figure 2 , on the other hand, depicts the $\mathrm{T}_{\min }$ area delineation results 


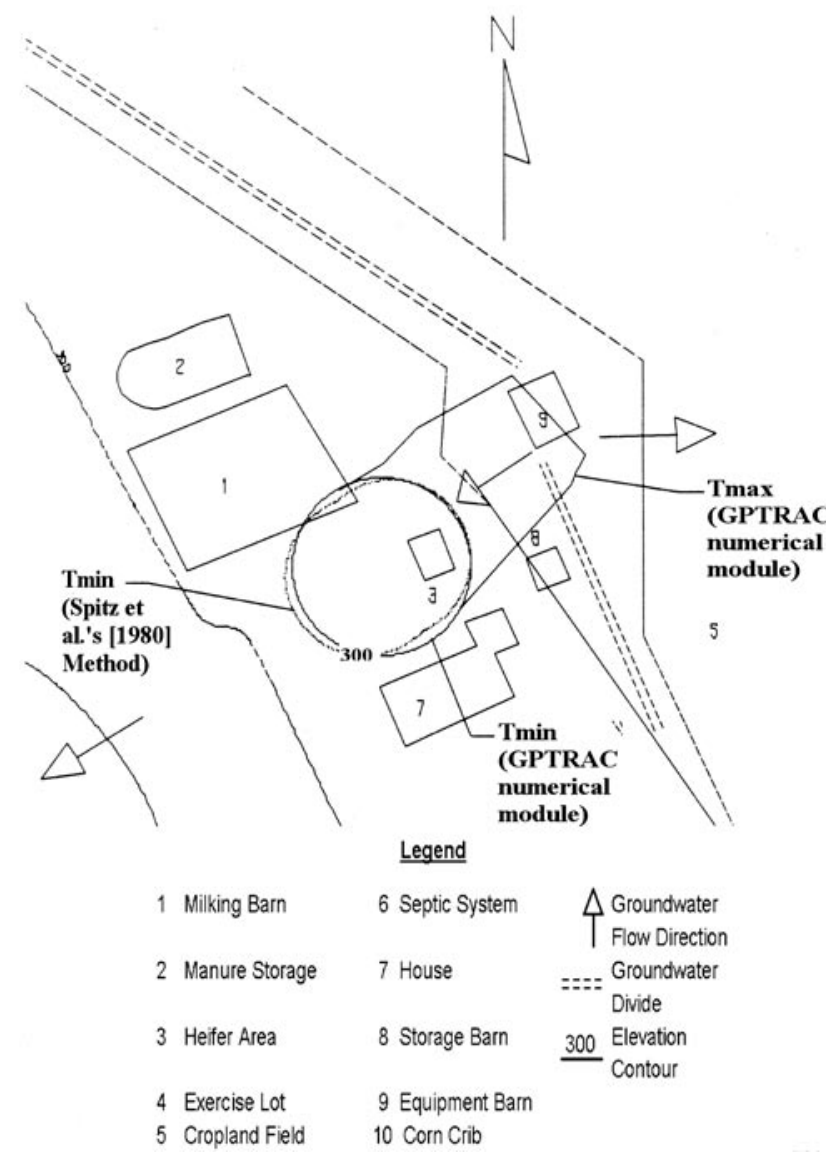

Figure 2

GPTRAC numerical module's (Doscher, 1992) and Spitz et al. (1980) method's results for Site 2

from the GPTRAC semi-analytical module and this model, and shows that the $\mathrm{T}_{\min }$ areas are nearly identical.

\section{Mull (1981)}

If radial flow is assumed, the Mull (1981) method delineates an area with a radius of $14.9 \mathrm{~m}$. However, it is highly unlikely that this delineated area will be the final Zone II since radial flow implies a flat water table which Doscher (1992) did not assume in his study. Furthermore, such delineation implies that the apparent groundwater flow velocity is negligible, which is certainly not true for the given $\mathrm{T}_{\max }$ value of $3726 \mathrm{~m}^{2} / \mathrm{d}$. However, for an initial delineation or for extremely low transmissivity values, the assumption of radial flow may be justified. Nevertheless, the assumption of uniform flow is more realistic for Site 2. The resulting $\mathrm{T}_{\max }$ area yielded an elongated ellipse, $29.8 \mathrm{~m}$ wide at the well and $3500 \mathrm{~m}$ long. This area captured the heifer containment area and a very small portion of the barn, in addition to extending beyond the study area boundaries. The $\mathrm{T}_{\min }$ area, on the other hand, is of a somewhat circular shape with an average radius of $16.8 \mathrm{~m}$ and also included a portion of the barn and heifer containment area.

A visual comparison between the Mull (1981) method and the EPA-suggested methods showed, for instance, that the RESSQC module's $T_{\max }$ results were practically identical (see Fig. 3). The $\mathrm{T}_{\max }$ delineation results, on the other hand, were quite different between this method and the MWCAP and GPTRAC semi-analytical modules. The $\mathrm{T}_{\min }$ areas differed in size as well, but were of the same general shape. The GPTRAC numerical module produced very similar results for the selected

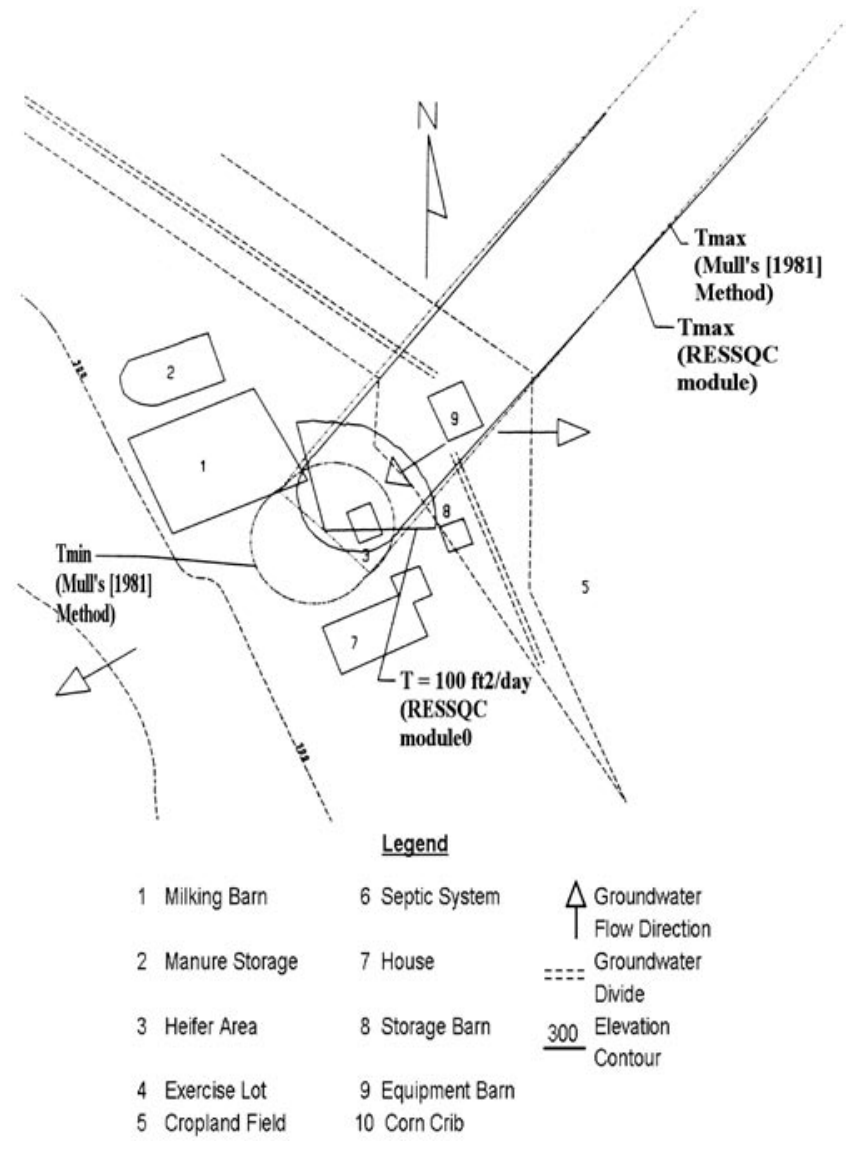

Figure 3

RESSQC module's (Doscher, 1992) and Mull (1981) method's results for Site 2

$\mathrm{T}_{\min }$ value, but included more area down-gradient for the chosen $\mathrm{T}_{\max }$ value.

\section{Rehse (1977)}

A review of the soil properties for Site 2 (Glenville, Chester, and Glenelg soils) revealed that the highest water table could reach $0.15 \mathrm{~m}$ from the ground surface (SCS, 1985). For the given crops (corn, soybeans, alfalfa, and barley) at the site, the potential root zone depth could reach $2 \mathrm{~m}$ (Doorenbos and Pruitt, 1977). Thus, no cleansing action of the unsaturated zone can be expected.

\section{Site 3}

Site 3 in Doscher's (1992) study is a dairy farm located at approximately $39^{\circ} 52^{\prime}$ North latitude and $76^{\circ} 06^{\prime}$ 'West latitude in southern Lancaster County, Pennsylvania. Located at an approximate elevation of $186 \mathrm{~m}$ above sea level, the farm buildings lie in an area in which the elevation decreases in a southeasterly direction. A local topographic high is found directly to the north of the area in question. The farm's well-bore is cased above ground to reduce the risk of direct contamination and is located next to a field which is usually planted with tobacco. Little is known about the well itself. Possible contamination sources include a milking barn, situated to the south of the wellbore, a large manure storage pit, located down-gradient from the well and south of the milking barn, a septic tank, situated $91 \mathrm{~m}$ down-gradient of the well-bore, and a leach field. A map of the site is shown in Fig. 4.

In Doscher's (1992) study, the well in question was operated exclusively to supply water for the milking operation, while a separate well, located approximately $91 \mathrm{~m}$ down- 


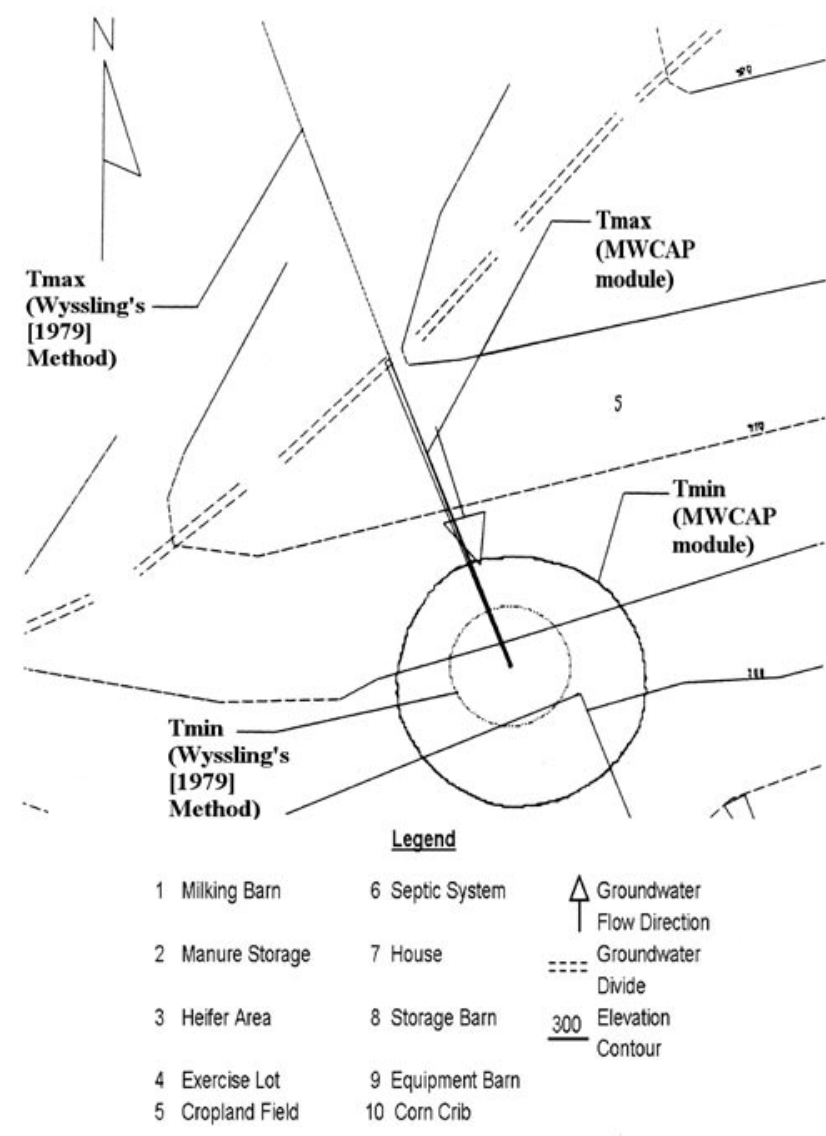

Figure 4

MWCAP module's (Doscher, 1992) and Wyssling (1979) method's results for Site 3

gradient, was used to provide drinking water for the seven dairy farm residents. No well interference effects could be assumed to occur since the second well was located downgradient. Doscher (1992) determined the ambient groundwater flow angle to be $291^{\circ}$. Doscher (1992) estimated a daily water use of $14326 \ell / d$.

\section{Delineation results of the EPA-suggested methods for Site 3 (Doscher, 1992)}

\section{Arbitrary fixed radius method}

Doscher (1992) selected arbitrary radii of $15.2 \mathrm{~m}, 30.5 \mathrm{~m}$, and $121.9 \mathrm{~m}$. While the $15.2 \mathrm{~m}$ radius area did not include any major contamination sources, the $30.5 \mathrm{~m}$ radius area contained segments of the heifer containment area, milking barn, house, and equipment barn. The $121.9 \mathrm{~m}$ radius area, on the other hand, embraced all farm buildings and exercise lots, the leach field, the septic tank, as well as major portions of cropland.

\section{Calculated fixed radius method}

The calculated fixed radii obtained from the volumetric method for 1-year, 5-year, and 20-year TOTs by Doscher (1992) were $30.5 \mathrm{~m}, 73.8 \mathrm{~m}$, and $147.8 \mathrm{~m}$, respectively. The 1-year radius area included more area than the $30.5 \mathrm{~m}$ arbitrary fixed radius area. Whereas the 5-year radius area embraced all farm buildings, the septic tank, portions of the leach field, turn-out lot, and cultivated field to the north of the heifer barn, as well as the heifer barn and manure storage pit, the 20-year radius area extended beyond the study area boundaries.

\section{Analytical models}

Using the given $\mathrm{T}_{\max }$ value of $6210 \mathrm{~m}^{2} / \mathrm{d}$ with the RESSQC module furnished a $30.5 \mathrm{~m}$ wide area oriented along the inferred direction of groundwater flow, while the delineation using the $\mathrm{T}_{\min }$ value of $0.006 \mathrm{~m}^{2} / \mathrm{d}$ produced a circular WHPA with a $30.4 \mathrm{~m}$ radius. This WHPA included parts of the planted field and the milking barn. Using the estimated $\mathrm{T}_{\max }$ value with the MWCAP module, on the other hand, yielded a straight, narrow line of $70.4 \mathrm{~m}$ in length. Unfortunately, the width of the $\mathrm{T}_{\mathrm{max}}$ area could not be determined with certainty. However, the $T_{\max }$ area did pass through a portion of the heifer containment area. The delineation with the MWCAP module, using the selected $\mathrm{T}_{\min }$ value, nevertheless, yielded a rotund ellipse that embraced portions of the heifer containment area and milking barn, as well as the entire house. Nearly identical results were produced by the GPTRAC semi-analytical and MWCAP modules. While the GPTRAC semi-analytical module yielded a straight line of $68.3 \mathrm{~m}$ length directed along the inferred direction of groundwater flow for the used $\mathrm{T}_{\max }$ value, the delineation with the selected $\mathrm{T}_{\min }$ value produced an unidentifiable result.

\section{Numerical model}

With the $\mathrm{T}_{\min }$ value, a circle with an approximate radius of 19.0 m resulted from the GPTRAC numerical module's delineation, employing the pre-selected $\mathrm{T}_{\min }$ value. The circle embraced portions of the heifer containment area and milking barn. The $\mathrm{T}_{\max }$ area delineation included all delineated area from the $\mathrm{T}_{\text {min }}$ value and also additional area in the direction of groundwater flow and beyond the local groundwater divide.

\section{Delineation results of the German methods for Site 3}

\section{Wyssling (1979)}

The $\mathrm{T}_{\max }$ delineation resulted in a very narrow, straight line oriented along the direction of groundwater flow. This area did not embrace any farm buildings, but instead passed through cropland and extended beyond the local groundwater divide. As for Site 2, the $\mathrm{T}_{\min }$ area computation resulted in a circle, but with a slightly smaller radius, namely of $12.2 \mathrm{~m}$. The delineated WHPA included a very minor portion of the milking barn and mostly consisted of the cropland up-gradient from the well.

The delimited $\mathrm{T}_{\max }$ areas for the RESSQC module and Wyssling's (1979) model were revealed to be quite different in dimensions, even though they were both oriented in the same direction. The $\mathrm{T}_{\max }$ area from the RESSQC module was much wider and, therefore, included much more area to be protected. The $\mathrm{T}_{\text {min }}$ areas, on the other hand, were both circular in shape, but the RESSQC module's resulting area encompassed more than twice the area of the $T_{\text {min }}$ area delineated by Wyssling's (1979) method. Hence, the RESSQC module's $\mathrm{T}_{\text {min }}$ area included a greater portion of the milking barn as a potential contamination source for the well-head. Figure 4, on the other hand, shows some similarities between this method and results of the MWCAP module. Since the MWCAP module incorporates local boundaries, it is seen not to cross the local groundwater divide. The $\mathrm{T}_{\min }$ areas are similar; however, the result of Wyssling's (1979) method is more circular and also includes much less area. The GPTRAC semi-analytical module, in contrast, was not capable of delineating an area for the given $\mathrm{T}_{\min }$ value. Once again, the $\mathrm{T}_{\max }$ area delineations by using the GPTRAC numerical module were quite different in comparison to Wyssling's (1979) $\mathrm{T}_{\text {max }}$ area delineation results. One possible explanation for this might be that the principal flow axis began to curve just before reaching the local groundwater divide. While Wyssling's (1979) method 


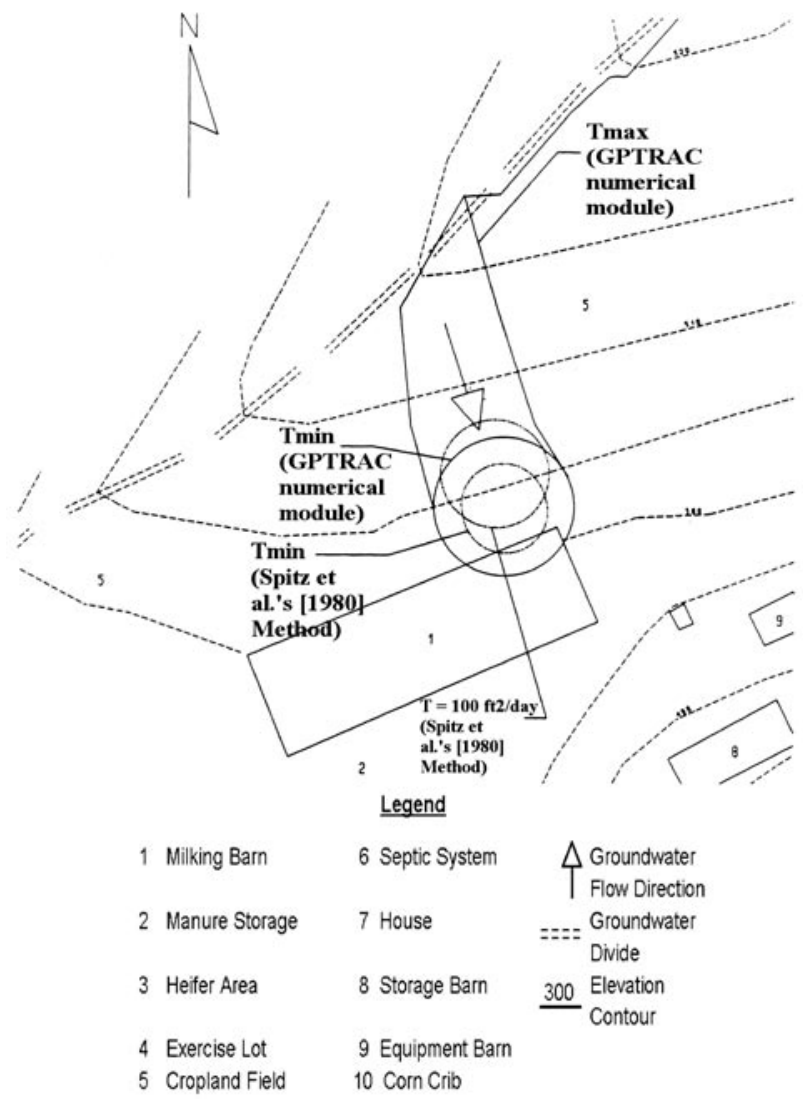

Figure 5

GPTRAC numerical module's (Doscher, 1992) and Spitz et al. (1980) method's results for Site 3

assumes a completely straight flow axis, the GPTRAC numerical module is capable of incorporating a curved groundwater flow axis when delineating WHPAs. Furthermore, the resulting $\mathrm{T}_{\text {min }}$ area from the GPTRAC numerical module was approximately two and a half times larger than that obtained from Wyssling's (1979) method.

\section{Spitz et al. (1980)}

As for Site 2, Spitz et al.'s (1980) method could not be used to delineate an area for the estimated $\mathrm{T}_{\max }$ value. The $\mathrm{T}_{\min }$ area, on the other hand, resulted in a circular shape with an approximate average radius of $12.6 \mathrm{~m}$. This delineated area consisted mostly of the planted field adjacent to the well. The up-gradient and down-gradient dispersivity factors were both evaluated to be equal to 1.0, implying there is only convective flow for the chosen $\mathrm{T}_{\min }$ value.

The simulation results revealed that the $T_{\min }$ area delineated by the RESSQC module was more than five times as big as the $\mathrm{T}_{\min }$ area delineated by this method. Likewise, the MWCAP module delineation for the chosen $\mathrm{T}_{\min }$ value resulted in a much larger area and, thus, enclosed a greater percentage of the planted field up-gradient from the well and milking barn. As depicted in Fig. 5, the $\mathrm{T}_{\min }$ area delineated by the GPTRAC numerical module embraces, similarly to the Site 2 delineation, a larger area than this German delineation model.

\section{Mull (1981)}

If radial flow is assumed, then this method delineates a circular area with a radius of $12.2 \mathrm{~m}$. As for Site 2, this assumption is only appropriate for an aquifer with negligible groundwater

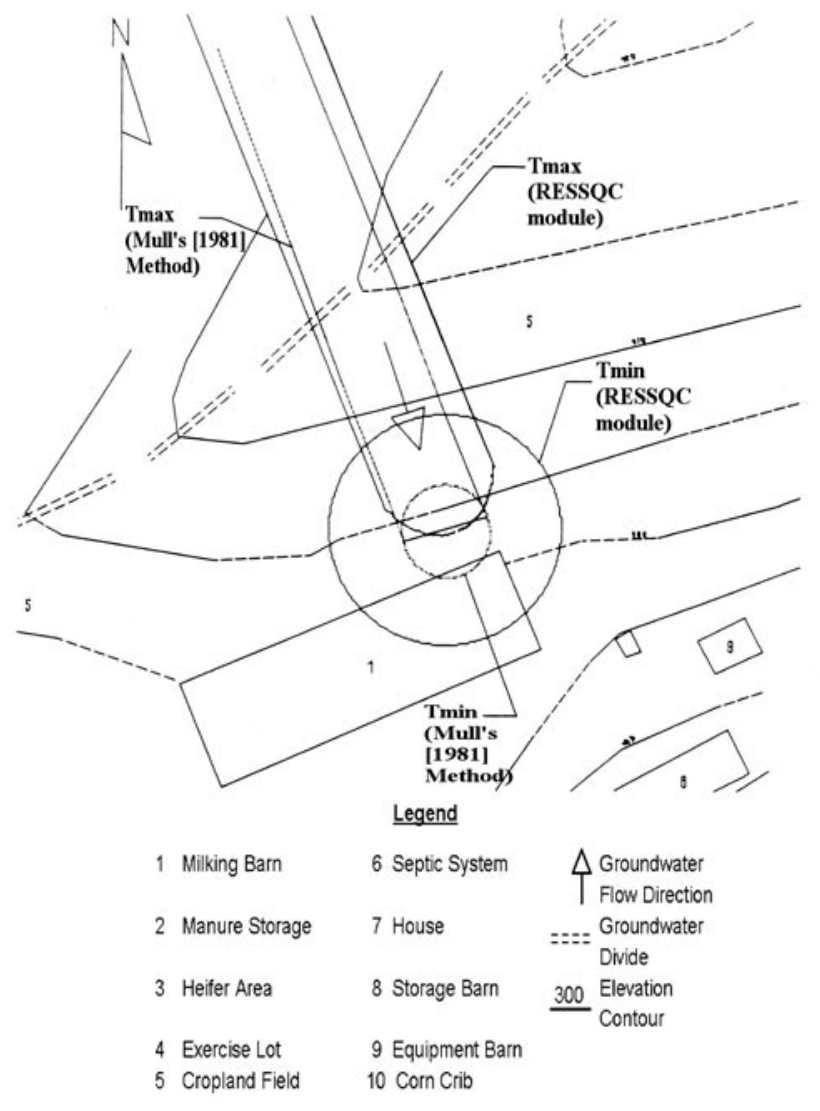

Figure 6

RESSQC module's (Doscher, 1992) and Mull (1981) method's results for Site 3

flow and a flat water table. On the contrary, if uniform flow is assumed for Site 3, then the delineated $\mathrm{T}_{\max }$ area results in an elongated ellipse with a width of $24.4 \mathrm{~m}$ at the well. From the computational results (see Fig. 6), it is seen that the $T_{\max }$ area extends to the calculated stagnation point. This area extends beyond the local groundwater divide and consists mostly of the cropland up-gradient from the well-bore. The $\mathrm{T}_{\min }$ area, on the other hand, results in a somewhat circular shape that covers a portion of the milking barn as well as cropland.

From Fig. 6, it is clear that this method and the RESSQC module produce practically identical results for the delineated $\mathrm{T}_{\max }$ areas. The $\mathrm{T}_{\min }$ area delineation for the RESSQC module, on the other hand, comprises twice as much as area as for this method. The MWCAP module's results did not compare well with this method's results for either the $\mathrm{T}_{\max }$ or $\mathrm{T}_{\min }$ case. Furthermore, the $\mathrm{T}_{\text {max }}$ areas delineated by the GPTRAC semi-analytical module and this method also did not compare well. The $\mathrm{T}_{\max }$ and $\mathrm{T}_{\min }$ area delineations by the GPTRAC numerical module, on the other hand, shared more similarities with the areas delineated by Mull's (1981) method. The difference between these two techniques can possibly be explained by the GPTRAC numerical module's ability to consider a non-linear flow axis, which Mull's (1981) method cannot.

\section{Rehse (1977)}

The soil properties for Site 3 (Chester and Glenelg soils) revealed that the highest water table could reach a height of $1.8 \mathrm{~m}$ (SCS, 1985). If the condition set by Rehse (1977) to neglect the first 4 $\mathrm{m}$ in the computations is disregarded on the basis that accurate soil information for the site is assumed for the given crops (corn, 


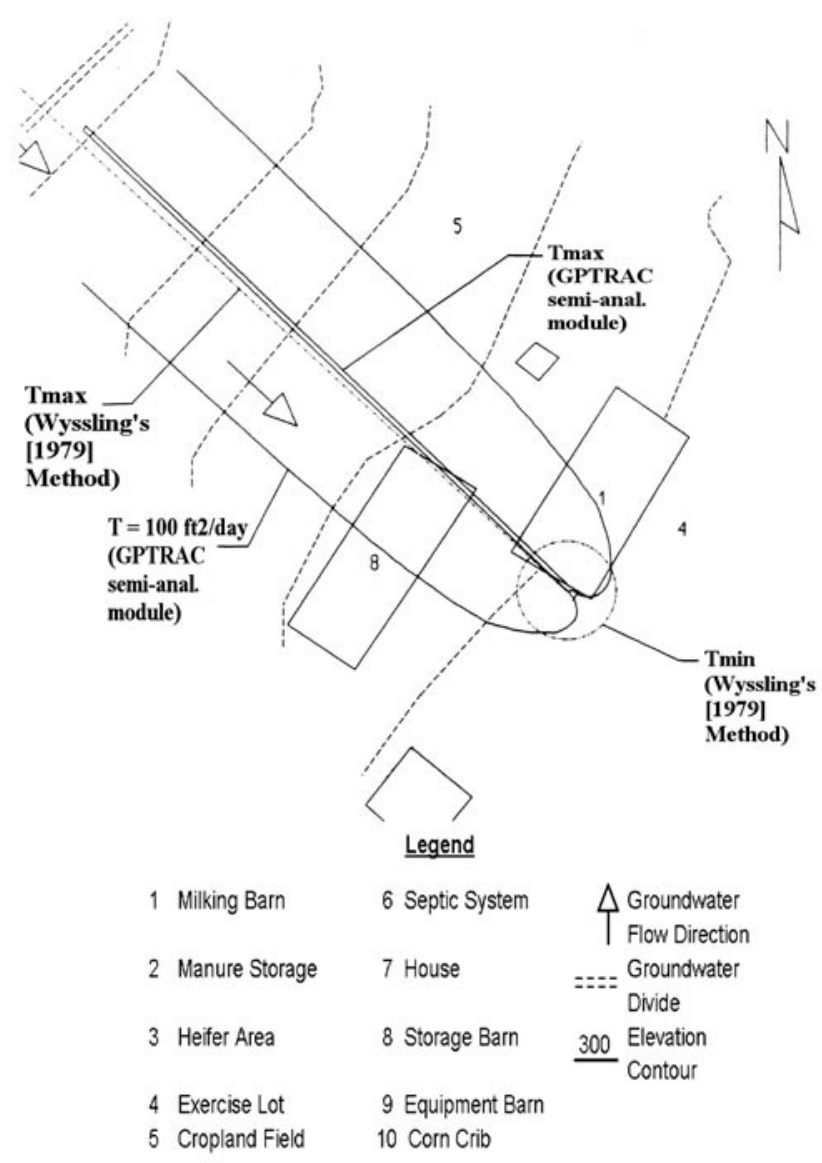

Figure 7

GPTRAC semi-analytical module's (Doscher, 1992) and Wyssling (1979) method's results for Site 4

alfalfa, barley, and tobacco), then the root zone depth could potentially reach a maximum depth of $2 \mathrm{~m}$ (Doorenbos and Pruitt, 1977; Knisel, 1980). Thus, the unsaturated zone for this site cannot be expected to have any regeneration capabilities.

\section{Site 4}

Site 4 in Doscher's (1992) study is located at approximately $39^{\circ} 50^{\prime}$ North latitude and $76^{\circ} 12^{\prime}$ 'West longitude in southern Lancaster County, Pennsylvania. The farm buildings in question lie at an approximate elevation of $180 \mathrm{~m}$ a.m.s.l. and are in an area in which elevation decreases in a south-easterly direction. A local high elevation is found to the north-west of the farm buildings. The well-head is situated adjacent to a large milking barn. Cropland is found up-gradient form the storage barns, which are located up-gradient from the well. In addition, a septic tank as well as a leach field are situated south of the house. The leach field is approximately $9 \mathrm{~m}$ down-gradient in a fallow field. Figure 7 gives more insight into the relative location of the possible pollution sources. Doscher (1992) approximated the farm's daily water use to equal $9478 \mathrm{l} / \mathrm{d}$ and the angle of ambient groundwater flow to be $315^{\circ}$.

\section{Delineation results of the EPA-suggested methods for Site 4 (Doscher, 1992)}

\section{Arbitrary fixed radius method}

Doscher (1992) selected radii of $15.2 \mathrm{~m}, 30.5 \mathrm{~m}$ and $121.9 \mathrm{~m}$ for delineation. While the $15.2 \mathrm{~m}$ radius area covered approx- imately one-third of the milking barn, the $30.5 \mathrm{~m}$ radius area encompassed a greater portion of the milking barn as well as an adjacent lying grassy lawn. The $121.9 \mathrm{~m}$ radius area, on the other hand, embraced the septic tank, leach field, farm buildings, major portions of cropland, and all exercise lots.

\section{Calculated fixed radius method}

The calculated fixed radii obtained from the volumetric method for the 1-year, 5-year, and 20-year TOTs in Doscher's (1992) study were $25.6 \mathrm{~m}, 57.3 \mathrm{~m}$, and $114.3 \mathrm{~m}$, respectively. Therefore, the 1-year radius area included an area slightly smaller than that enclosed by the $30.5 \mathrm{~m}$ arbitrary fixed radius. This area encompassed part of the surrounding residential area and milking barn. The 5-year radius area, on the other hand, included the septic tank, all farm buildings, as well as portions of the leach field and turn-out lot. In addition, the 20 -year radius area encompassed the septic tank, surrounding planted fields, all farm buildings, and turn-out lots. However, this area extended beyond the study area.

\section{Analytical models}

The RESSQC module produced a tear-drop shape $T_{\max }$ area along the supposed direction of groundwater flow. The apex of the area was found to lie at the well-bore. Portions of a storage barn and milking barn, as well as up-gradient cropland were determined to lie in that area. The $\mathrm{T}_{\min }$ area, on the other hand, was in the shape of a circle with a radius of $17.7 \mathrm{~m}$ and included a portion of the milking barn and residential lawn.

The $T_{\text {max }}$ area delineated by the MWCAP module, on the other hand, was a straight, narrow line with a length of $126 \mathrm{~m}$ and an uncertain width. This area was seen to extend beyond the local groundwater divide and through cropland. The delineated $\mathrm{T}_{\min }$ area yielded a circle with a radius of $22 \mathrm{~m}$ and embraced a portion of the milking barn. Moreover, Doscher's (1992) results showed that the delineated $\mathrm{T}_{\max }$ area from the GPTRAC semianalytical module was identical to the $\mathrm{T}_{\max }$ area delimited by the MWCAP module, while the $\mathrm{T}_{\min }$ delineation resulted in an unidentifiable WHPA. After increasing the selected $\mathrm{T}_{\text {min }}$ value of $0.007 \mathrm{~m}^{2} / \mathrm{d}$ to $9.29 \mathrm{~m}^{2} / \mathrm{d}$, an oblong area with a width of $41 \mathrm{~m}$ was computed and included segments of the cropland and milking barn.

\section{Numerical model}

The GPTRAC numerical module produced a circular area with a radius of $11 \mathrm{~m}$ for the given $\mathrm{T}_{\min }$ value. This area contained parts of the cropland and adjacent milking barn. The $\mathrm{T}_{\max }$ area, on the other hand, included all the delineated area from the $\mathrm{T}_{\min }$ area delineation as well as additional area oriented along the inferred direction of groundwater flow.

\section{Delineation results of the German methods for Site 4}

\section{Wyssling (1979)}

The $\mathrm{T}_{\max }$ delineation resulted in a very narrow, straight line that extended beyond the study area boundaries and passed through the storage barn, milking barn, and adjacent cropland. The $\mathrm{T}_{\text {min }}$ area delineation resulted in a circle with a radius of $9.5 \mathrm{~m}$, and included a portion of the milking barn.

A comparison of the $\mathrm{T}_{\max }$ areas delineated by Wyssling's (1979) method and the RESSQC module presented a significant difference in areas. The RESSQC module's delineation consisted of more local area, but did not extend to the local groundwater divide. Both models, however, produced a circular area for the $\mathrm{T}_{\min }$ area. Nevertheless, the RESSQC module's $\mathrm{T}_{\min }$ area was 


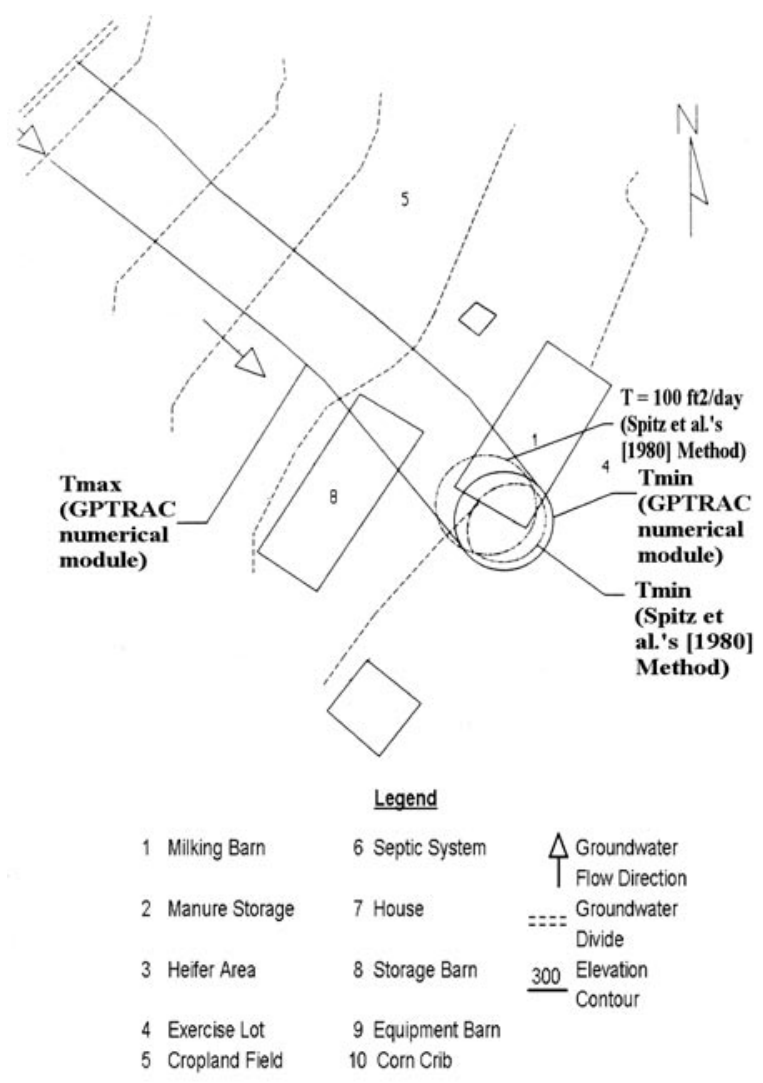

Figure 8

GPTRAC numerical module's (Doscher, 1992) and Spitz et al. (1980) method's results for Site 4

more than three times as large as the Wyssling (1979) method's $\mathrm{T}_{\min }$ area. The MWCAP module's delineation results for $\mathrm{T}_{\min }$ and $\mathrm{T}_{\max }$, however, were much more comparable. Nevertheless, once again, the MWCAP module's $\mathrm{T}_{\min }$ area incorporated more potential contamination sources. In Fig. 7 , it is seen that the $T_{\text {max }}$ areas for the GPTRAC semi-analytical module and this method are nearly identical.

Nonetheless, the $\mathrm{T}_{\max }$ area from the GPTRAC semi-analytical module does not extend to the local groundwater divide. With respect to the GPTRAC numerical simulation, the $T_{\min }$ areas for both models were nearly identical. In contrast, the $\mathrm{T}_{\max }$ areas were quite distinct. Even though oriented in the same direction, the GPTRAC numerical module's $\mathrm{T}_{\max }$ area was much wider and, therefore, contained areas not included in the $\mathrm{T}_{\max }$ area delineated by Wyssling's (1979) method.

\section{Spitz et al. (1980)}

As for Sites 2 and 3, this method could not be used to delineate an area for the estimated $\mathrm{T}_{\text {max }}$ value. Nevertheless, the $\mathrm{T}_{\text {min }}$ area delineation yielded a circular (elliptical) shape of approximate average radius of $8 \mathrm{~m}$. The $T_{\min }$ area basically consisted of a portion of the milking barn and the surrounding grassy lawn. The up-gradient and down-gradient dispersivity factors were determined to be both equal to 1.0 (Spitz et al., 1980). Thus, for the selected $\mathrm{T}_{\min }$ value, no dispersion effects were observed.

The RESSQC module's $\mathrm{T}_{\min }$ area delineation resulted in a much larger protection zone, encompassing much more of the milking barn, in comparison to Spitz et al.'s (1980) results. A similar difference between the MWCAP module and the Spitz et al. (1980) method's $\mathrm{T}_{\min }$ delineation was observed. Figure 8 portrays the $\mathrm{T}_{\min }$ results from this method and the GPTRAC

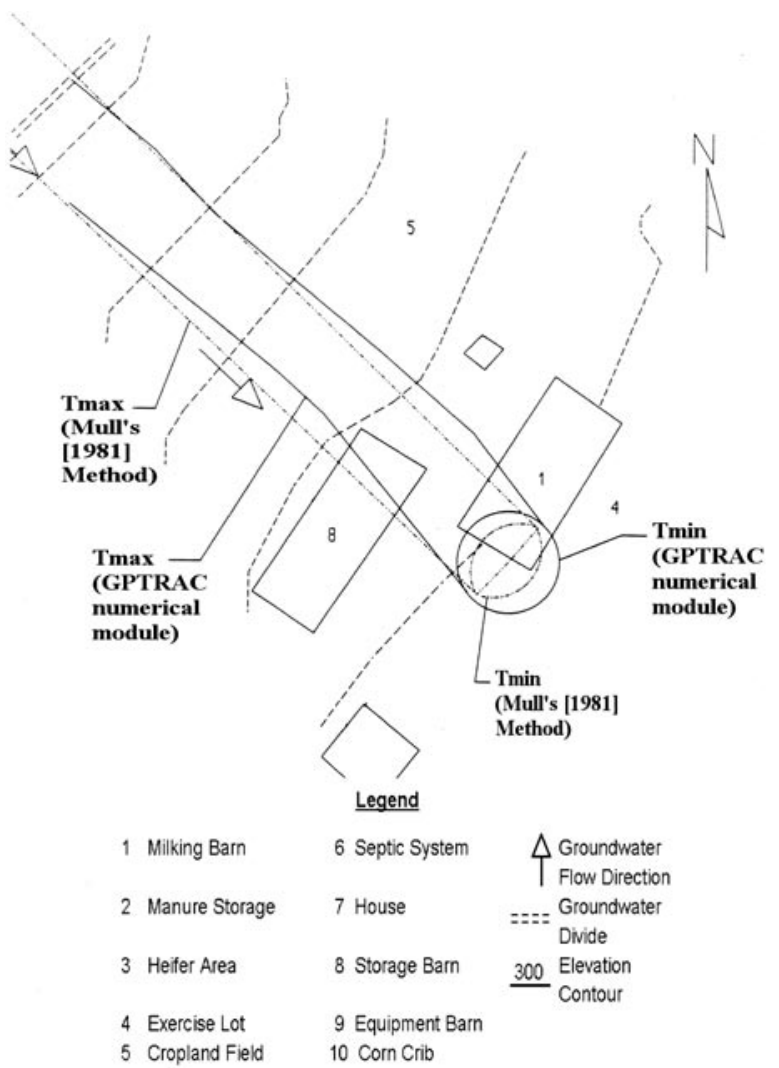

Figure 9

GPTRAC numerical module's (Doscher, 1992) and Mull (1981) method's results for Site 4

numerical module. The $\mathrm{T}_{\min }$ areas compare fairly well and basically include the same potential pollution sources.

\section{Mull (1981)}

By assuming radial flow, this method delineated a circle with a radius of $9.5 \mathrm{~m}$. As previously mentioned, this assumption is not realistic for the cases examined in this study. Instead, uniform flow was assumed. The delineated $\mathrm{T}_{\max }$ area was very long and $19.0 \mathrm{~m}$ wide that stretched from the computed location of the stagnation point across the study boundaries. The segment consisted of portions of the milking barn, storage barn, as well as up-gradient cropland. The calculated $\mathrm{T}_{\min }$ area, on the other hand, was found to be of a circular shape that only embraced a part of the milking barn and the adjacent grassy lawn.

The Mull (1981) method's $T_{\max }$ area computation embraced only the starting point of the $\mathrm{T}_{\max }$ area delineated by the RESSQC module. The $\mathrm{T}_{\min }$ area from this method was much smaller than the RESSQC module's $\mathrm{T}_{\min }$ area determination. The $\mathrm{T}_{\max }$ area delineated by the MWCAP module was included in the Mull (1981) method's $T_{\max }$ area delineation. Depending on which delineation is deemed to be more realistically accurate, either under-protection or overprotection was present in this case. The $\mathrm{T}_{\min }$ area from the MWCAP module was more than five times as large as that from this method. Similar to the MWCAP module's delimitation, the $\mathrm{T}_{\max }$ area delineated by the GPTRAC semi-analytical module was completely included in Mull (1981) method's $\mathrm{T}_{\max }$ area demarcation. As seen from Fig. 9, the $\mathrm{T}_{\max }$ area computations from this method and the GPTRAC numerical module were quite similar in shape and dimensions. However, the GPTRAC numerical module's $\mathrm{T}_{\max }$ area was slightly shifted in a north-easterly direction from Mull (1981) method's 


\begin{tabular}{|l|l|l|}
\hline \multicolumn{3}{|c|}{ TABLE 2 } \\
Glenelg (Gb) soil texture data (SCS, 1985) \\
\hline $\begin{array}{l}\text { Soil name and } \\
\text { map symbol }\end{array}$ & Depth (m) & USDA texture \\
\hline & $0-0.2032$ & Silt loam \\
\hline Glenelg (Gb) & $0.2032-0.5588$ & $\begin{array}{l}\text { Channery silt loam, } \\
\text { silty clay loam, } \\
\text { loam }\end{array}$ \\
\hline & $0.5588-1.524$ & $\begin{array}{l}\text { Loam, sandy loam, } \\
\text { channery loam }\end{array}$ \\
\hline
\end{tabular}

$\mathrm{T}_{\max }$ delineated area, which was probably due to the fact that the numerical module was capable of including the slight bend of the groundwater flow axis, as was observed from the topography at the north-eastern corner of the storage barn. The $T_{\min }$ area delineations from both models were in addition similar. However, the numerical model's delineated WHPA covered slightly more area.

\section{Rehse (1977)}

Similarly to Site 3 , the soil properties for this site (Glenelg soil) indicate that the highest water table could reach $1.8 \mathrm{~m}$ below the ground surface. Due to the fact that alfalfa was found at this site, Rehse's (1977) method cannot be used to consider the regeneration capabilities of the unsaturated zone.

However, the authors believe that it is important to demonstrate the capabilities of this method by a hypothetical example derived from the given conditions for this site. Assuming that we can disregard the condition of ignoring the first $4 \mathrm{~m}$ on the basis of having site-specific soil conditions information; the only crop growing at this site is alfalfa; and alfalfa's maximum root zone depth at this site is $1 \mathrm{~m}$, one can compute the soil's cleansing ability as follows: From knowing the highest water table height found at the site as well as the other data above, $0.829 \mathrm{~m}$ are, thus, available for possible cleansing action of the soil. From Table 2, for the soil type (Glenelg soil) present at Site 4 , one can calculate the degree of cleansing, $M_{d}$, from the given USDA textures:

$$
M_{d}=(0.2032)(0.4)+(0.3556)(0.5)+(0.2692)(0.5)=0.3937
$$

Therefore, the required remaining residence time is:

$$
T=50(1-0.3937)=30.3 \text { days }=31 \text { days }
$$

Hence, the German Zone II only necessitates a 31d line instead of a $50 \mathrm{~d}$ line. If one now calculates Zone II by, for example, Wyssling's (1979) method, then the $T_{\min }$ area translates into a circle with a radius of $2.3 \mathrm{~m}$, whereas the Tmax area is a very long, narrow strip of $0.02 \mathrm{~m}$ width and $326 \mathrm{~m}$ length, directed in a north-easterly direction and extending beyond the groundwater divide. These results are plotted in Fig. 10 along with the earlier results of Wyssling's (1979) method (i.e., $50 \mathrm{~d}$ line results). As seen from Fig. 10, the $\mathrm{T}_{\max }$ areas remain basically the same for both the $31 \mathrm{~d}$ - and $50 \mathrm{~d}$ lines. However, the $31 \mathrm{~d}$ line area for the $T_{\min }$ value is significantly reduced, therefore, demonstrating the usefulness of considering the cleansing capabilities of the unsaturated zone.

\section{Conclusions}

Depending on financial and other resources available in an agricultural operation, Doscher (1992) determined that at least one

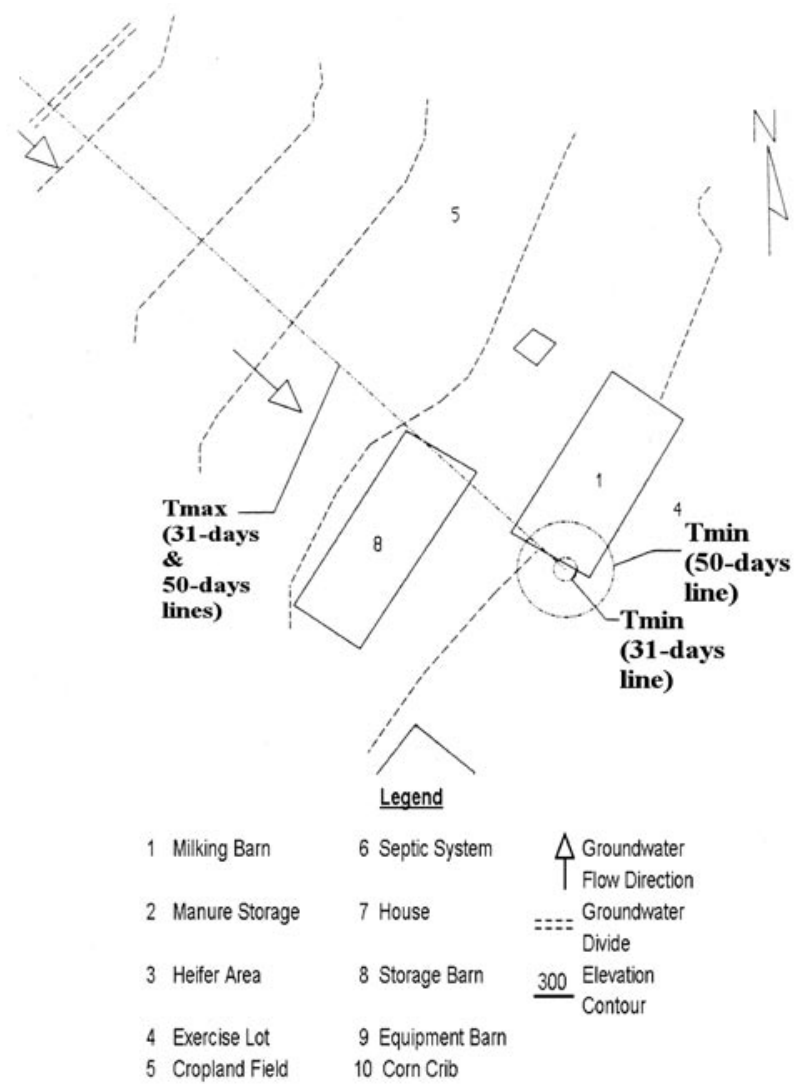

Figure 10

31-days and 50-days line from the Wyssling (1979) method for Site 4

of the six methods for delineating a WHPA as identified and recommended by the EPA (1987) can be used in an agricultural setting. This paper presented these methods as well as German WHPA delineation models to evaluate and examine the variations in the simulation results when delineating WHPAs in agricultural regions. Based on the wide range of dimensions and shapes of areas delineated by the EPA-recommended and German methods, it is not easy to conclude which model most reliably, effectively, and accurately represents the area around a well that needs to be protected from potential contamination sources. A significant portion of the variability in the models was undoubtedly brought about by the lack of more site-specific values for the hydraulic conductivity. While the delineated shapes typically varied little between the EPA-suggested and German models, the computed dimensions often showed a greater variation. For areas delineated using a pre-chosen $\mathrm{T}_{\text {min }}$ value, these distinctions were less prevalent. Tables 3 and 4 summarise the delineation results for the analytical and numerical EPA-recommended modules and German methods based on the estimated $\mathrm{T}_{\min }$ and $\mathrm{T}_{\max }$ values, respectively.

It is noteworthy that the delineation results of the various German WHPA delineation methods often came very close to the delineated results of the numerical model. For the $\mathrm{T}_{\text {max }}$ cases, the results were less striking; however, as seen from Table 4, the only method that correlated fairly closely with the numerical model's delineated area was Mull's (1981) method. In contrast, as seen from Table 3, the three examined German methods compare quite well with the output of the numerical module, when using the $\mathrm{T}_{\min }$ value. Particularly Wyssling's (1979) method gave in all three case studies extremely similar $\mathrm{T}_{\min }$ WHPA delineations with respect to the numerical model's 
TABLE 3

Comparison of EPA-suggested analytical/numerical methods with German methods for the $T_{\min }$ case

\begin{tabular}{|c|c|c|c|}
\hline Method & $\begin{array}{l}\text { Site } 2 \\
\left(T_{\min }=0.004 \mathrm{~m}^{2} / \text { day }\right)\end{array}$ & $\begin{array}{l}\text { Site } 3 \\
\left(T_{\min }=0.006 \mathrm{~m}^{2} / \text { day }\right)\end{array}$ & $\begin{array}{l}\text { Site } 4 \\
\left(T_{\min }=0.007 \mathrm{~m}^{2} / \text { day }\right)\end{array}$ \\
\hline RESSQC Analytical Module & Unidentifiable WHPA & $\begin{array}{l}\text { Circular WHPA: } \\
30.5 \text { m-radius }\end{array}$ & $\begin{array}{l}\text { Circular WHPA: } \\
18 \text { m-radius }\end{array}$ \\
\hline MWCAP Analytical Module & $\begin{array}{l}\text { Approx. circular WHPA: } 3 \\
2 \text { m-radius }\end{array}$ & $\begin{array}{l}\text { Approx. circular WHPA: } \\
28 \text { m-radius }\end{array}$ & $\begin{array}{l}\text { Circular WHPA: } \\
22 \text { m-radius } \\
\end{array}$ \\
\hline $\begin{array}{l}\text { GPTRAC Semi-Analyical } \\
\text { Module }\end{array}$ & \begin{tabular}{|l|} 
Circular WHPA: \\
32 m-radius \\
\end{tabular} & Unidentifiable WHPA & Unidentifiable WHPA \\
\hline GPTRAC Numerical Module & $\begin{array}{l}\text { Circular WHPA: } \\
16.5 \text { m-radius } \\
\end{array}$ & $\begin{array}{l}\text { Circular WHPA: } \\
19 \text { m-radius } \\
\end{array}$ & \begin{tabular}{|l} 
Circular WHPA: \\
11 m-radius \\
\end{tabular} \\
\hline Wyssling's (1979) Method & $\begin{array}{l}\text { Circular WHPA: } \\
15 \text { m-radius } \\
\end{array}$ & $\begin{array}{l}\text { Circular WHPA: } \\
12 \text { m-radius } \\
\end{array}$ & $\begin{array}{l}\text { Circular WHPA: } \\
9 \text { m-radius } \\
\end{array}$ \\
\hline Spitz et al.'s (1980) Method & $\begin{array}{l}\text { Approx. circular WHPA: } \\
18 \text { m-radius }\end{array}$ & $\begin{array}{l}\text { Approx. circular WHPA: } \\
13 \text { m-radius }\end{array}$ & $\begin{array}{l}\text { Approx. circular WHPA: } \\
8 \text { m-radius }\end{array}$ \\
\hline Mull's (1981) Method & $\begin{array}{l}\text { Approx. circular WHPA: } \\
17 \text { m-radius }\end{array}$ & $\begin{array}{l}\text { Approx. circular WHPA: } \\
25 \text { m-radius }\end{array}$ & \begin{tabular}{|l|} 
Elliptical WHPA: \\
19 m-width, 12 m-length
\end{tabular} \\
\hline
\end{tabular}

TABLE 4

Comparison of EPA-suggested analytical/numerical methods with German methods for the $T_{\max }$ case

\begin{tabular}{|c|c|c|c|}
\hline Method & $\begin{array}{l}\text { Site } 2 \\
\left(T_{\max }=3726 \mathrm{~m}^{2} / \text { day }\right)\end{array}$ & $\begin{array}{l}\text { Site } 3 \\
\left(T_{\max }=6219 \mathrm{~m}^{2} / \text { day }\right)\end{array}$ & $\begin{array}{l}\text { Site } 4 \\
\left(T_{\max }=6828 \mathrm{~m}^{2} / \text { day }\right)\end{array}$ \\
\hline RESSQC Analytical Module & $\begin{array}{l}\text { Approx. elliptical WHPA: } \\
30.5 \text { m wide \& very long }\end{array}$ & $\begin{array}{l}\text { Approx. elliptical WHPA: } \\
30.5 \text { m wide \& very long }\end{array}$ & $\begin{array}{l}\text { Tear drop-shaped WHPA: } \\
18 \text { m-radius, apex at wellhead }\end{array}$ \\
\hline MWCAP Analytical Module & $\begin{array}{l}\text { Narrow line: } \\
47 \text { m-length, uncertain width }\end{array}$ & $\begin{array}{l}\text { Narrow line: } \\
70 \text { m-length, uncertain width }\end{array}$ & $\begin{array}{l}\text { Narrow line: } \\
126 \text { m-length, uncertain width }\end{array}$ \\
\hline $\begin{array}{l}\text { GPTRAC Semi-Analyical } \\
\text { Module }\end{array}$ & $\begin{array}{l}\text { Narrow line: } \\
142 \text { m-length, uncertain width }\end{array}$ & $\begin{array}{l}\text { Narrow line: } \\
68 \text { m-length, uncertain width }\end{array}$ & $\begin{array}{l}\text { Narrow line: } \\
126 \text { m-length, uncertain width }\end{array}$ \\
\hline GPTRAC Numerical Module & $\begin{array}{l}\text { Approx. rectangular WHPA: } \\
16.5 \mathrm{~m} \text {-width, } 58 \mathrm{~m} \text {-length }\end{array}$ & $\begin{array}{l}\text { Approx. rectangular WHPA: } \\
19 \text { m-width, } 90 \text { m-length }\end{array}$ & $\begin{array}{l}\text { Approx. rectangular WHPA: } \\
11 \text { m-width, } 149 \text { m-length }\end{array}$ \\
\hline Wyssling's (1979) Method & $\begin{array}{l}\text { Narrow line: } \\
3505 \text { m-length, } 0.18 \mathrm{~m} \text {-width } \\
\end{array}$ & $\begin{array}{l}\text { Narrow line: } \\
8626 \text { m-length, } 0.06 \text { m-width } \\
\end{array}$ & $\begin{array}{l}\text { Narrow line: } \\
5243 \text { m-length, } 0.06 \text { m-width } \\
\end{array}$ \\
\hline Spitz et al.'s (1980) Method & Could not be applied & Could not be applied & Could not be applied \\
\hline Mull's (1981) Method & $\begin{array}{l}\text { Approx. elliptical WHPA: } \\
3505 \text { m-length, } 30 \text { m-width }\end{array}$ & $\begin{array}{l}\text { Approx. elliptical WHPA: } \\
8626 \text { m-length, } 24 \text { m-width }\end{array}$ & $\begin{array}{l}\text { Approx. elliptical WHPA: } \\
5243 \text { m-length, } 19 \text { m-width }\end{array}$ \\
\hline
\end{tabular}

output. If, as explicitly suggested by Wyssling (1979), an additional spatial safety margin is provided around the delineated WHPA by Wyssling's (1979) method, an exact WHPA match could be obtained. This interesting observation might actually explain why the German groundwater protection programme has been quite successful in the past, if the EPA's conclusion in its 1987 comprehensive report concerning the use of numerical models vs. other delineation methods is taken into consideration: 'Numerical models use mathematical approximations of groundwater flow and/or contaminant transport equations that can take into account a variety of hydrogeologic and contamination conditions. These models offer possibly the most accurate delineations, ....' Bearing these observations in mind, it should be reasonable to conclude that some of the German methods should probably be acceptable and, therefore, accurate enough for communities or private entities with limited financial resources, such as farms. It is recommended, however, that when delineating WHPAs, a minimum of two different methods be used to not only safeguard against accidental computational errors, but also to assess the effects of different assumptions that characterise each delineation model. Simpler methods, such as the arbitrary fixed radius, calculated fixed radius, or Mull's (1981) radial flow method, may be more useful and applicable in the initial phases of WHPA delineation or in settings where essentially isotropic and homogeneous conditions prevail, since such methods do not incorporate flow direction resulting from hydraulic gradients, the effect of aquifer characteristics, or hydrogeological variations. Ultimately, the selection of an appropriate WHPA delineation method will be contingent on the requirements and resources of the implementer.

The hypothetical example, derived from Site 4 conditions, showed the potential significance of considering and including the regeneration capabilities of an aquifer. As seen from the computational delineation results, the regenerating capacity of porous media often yields considerable reductions in the necessary protection areas, especially for lower transmissivity values.

\section{References}

BLANDFORD TN and HUYAKORN PS (1991) WHPA 2.0: A Modular Semi-Analytical Model for the Delineation of Well-head Protection Areas. Office of Ground-Water Protection, U.S. Environmental Protection Agency, Washington, DC. 
BLANDFORD TN and HUYAKORN, PS (1993) WHPA: Well Head Protection Area Delineation Code. Prepared for the U.S. Environmental Protection Agency. Version 2.2.

BOLSENKÖTTER H, BUSSE R, DIEDERICH G, HÖLTING B, HOHBERGER K, REGENHARDT H, SCHLOZ W, VILLINGER E and WERNER J (1984) Hydrogeologische Kriterien bei der Bemessung von Wasserschutzgebieten für Grundwassererfassungen. Geologisches Jahrbuch, Reihe C, Heft 36, E. Schweizerbart'sche Verlagsbuchhandlung, Hannover.

CLEARY TCBF and CLEARY RW (1991) Delineation of wellhead protection areas: Theory and practice. Water Sci. Technol. 24239 250.

DOORENBOS J and PRUITT WO (1977) Guidelines for predicting crop water requirements. FAO Irrigation and Drainage Paper No.24. Folio 631.6-FAO/24. FAO, Rome.

DOSCHER C (1992) Evaluation of Wellhead Protection Delineation Methods for Farmsteads in Pennsylvania. Master of Science Thesis. Department of Agricultural Engineering, The Pennsylvania State University, USA.

EPA (UNITED STATES ENVIRONMENTAL PROTECTION AGENCY) (1987) Guidelines for Delineation of Wellhead Protection Areas. Office of Groundwater Protection, EPA, Washington, DC, USA.

HOFMANN W and LILLICH W (1973) Problematik der Bemessung der Engeren Zone für Lockergesteinsaquifere. Z. Dtsch. Geol. Ges. 124 567-573.
KNISEL WG (1980) CREAMS: A Field Scale Model for Chemicals, Runoff, and Erosion from Agricultural Management Systems. Conservation Report No. 26, USDA, Washington, DC.

LENNOX JB (1993) New regulations foster wellhead protection efforts. Public Works 12459.

MULL R (1981) Ground-water protection zones. Geo. J. 5 473-481.

NAHRGANG G (1965) Über die Bemessung von Schutzzonen bei Grundwassererfassungsanlagen. Bohrtechn. Brunnenb. Rohrlb. 16 102-107.

REHSE W (1977) Elimination und Abbau von organischen Fremdstoffen, pathogenen Keimen und Viren im Lockergestein. Z. Dtsch. Geol. Ges. 128 319-329.

RENNER H (1972) Die Berücksichtigung nichtbindiger überdeckender Schichten bei der Bemessung von Wasserschutzgebieten.Unpublished Ph.D. Dissertation. Technische Hochschule, Graz, Austria.

SCS (SOIL CONSERVATION SERVICE) (1985) Soil Survey of Lancaster County, Pennsylvania. United States Department of Agriculture and the Soil Conservation Service.

SPITZ K, MEHLHORN H and KOBUS H (1980) Ein Beitrag zur Bemessung der engerenSchutzzone in Porengrundwasserleitern. Wasserwirtschaft 7011 365-369.

STROBL RO and ROBILLARD PD (2005) Review of EPA-recommended U.S. and German wellhead protection area delineation methods. J. Environ. Hydrol. 13 (3) 1-19.

WYSSLING L (1979) Eine neue Formel zur Berechnung der Zuströmungsdauer (Laufzeit) des Grundwassers zu einem Grundwasserpumpwerk. Ecol. Geol. Helv. 72 401-406. 